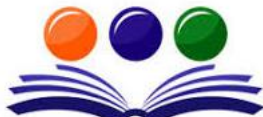

\title{
NESTLE INDIA LIMITED: GST ANTI-PROFITEERING COURT CASE
}

\author{
Reetu Murlidhar Tanwani, Dr. Mahendra. H. Maisuria \\ Research Scholar \\ Gujarat University. \\ Phone: 9925050088 \\ Email ID: ritzytanwani@gmail.com \\ Associate Professor-City C. U. Shah Commerce College \\ Phone: 9427605744 \\ Email ID: mahendramaisuriya@gmail.com
}

\begin{abstract}
The study focuses on the GST Anti-Profiteering Court case on the prestigious Fast Moving Consumer Goods (FMCG) Company Nestle India Limited. The company is alleged under the contravention of section 171 of Central Goods and Services Tax (CGST) Act-2017. The Company has been ordered to deposit approx. 90 crores to Consumer Welfare Funds (CWFs) on found guilty under the said Act. The Research paper focuses on the in-depth court case analysis of the company. The case is the detail investigation of the allegations made on the Nestle Company and termed as Anti-Profiteering case in GST. NAA-National Anti-Profiteering Authority conducts the detail investigation on the matter and presents facts and calculations however in defence Nestle claims and argues that all the allegations are false.
\end{abstract}

Keywords: Nestle India Limited, GST Anti-Profiteering, Section 171 of CGST Act-2017, DGAP, NAA.

\section{INTRODUCTION}

Section 171 of CGST Act, 2017 deals with Anti-Profiteering, according to the section 171(1) of CGST Act, any reduction in the tax rate should be passed to the customers by way of reduced price. The section protects consumer's interest and keep watch on the businesses. Any benefit which is because of GST must be passed to the consumers in the reduced price for e.g. cell phones were charged 13 to $24 \%$ before GST suppose one cell phone base price is Rs. 10,000 and before GST the rate of tax was $15 \%$ and after GST it is $12 \%$ so the calculation would be,

\begin{tabular}{|l|l|l|l|}
\hline Base Price & 10,000 & Base Price & 10,000 \\
\hline+ Tax before GST 15\% & 1,500 & + Tax in GST 12\% & 1,200 \\
\hline $\begin{array}{l}\text { Total Price paid by } \\
\text { Customer }\end{array}$ & 11,500 & $\begin{array}{l}\text { Total Price paid by } \\
\text { Customer }\end{array}$ & 11,200 \\
\hline
\end{tabular}

Thus, after GST customer should get the phone Rs 300 cheaper but what happens in the profiteering activities producers increase the base price and steal the benefit of the customers.

Taking same example with profiteering,

\begin{tabular}{|l|l|l|l|}
\hline Base Price & 10,000 & Base Price & 10,200 \\
\hline+ Tax before GST 15\% & 1,500 & + Tax in GST 12\% & 1,224 \\
\hline $\begin{array}{l}\text { Total Price paid by } \\
\text { Customer }\end{array}$ & 11,500 & $\begin{array}{l}\text { Total Price paid by } \\
\text { Customer }\end{array}$ & 11,424 \\
\hline
\end{tabular}

In this way the base price after GST was increased from 10,000 to 10,200 so the customer has no advantage of GST and producer or manufacturer took the advantage and earned extra profit. This is not allowed under GST System and termed as profiteering activity.

To keep watch on such profiteering activities NAA-National Anti-Profiteering Authority was formed in which standing and screening committees works at state level to take such complaints from the customers and DGAPDirector General of Anti-Profiteering conducts the detail investigation and calls the parties for the clarifications and documents and analysis the matters in detail to ensure justice to the consumers. After GST such cases of profiteering rose many customers complained about such profiteering activities to the standing and screening committees and in investigation many famous companies found guilty and some were proven innocent. 


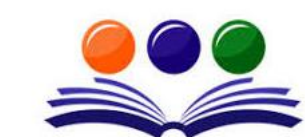

GRAND ACADEMIC PORTAL RESEARCH JOURNALS

LITERATURE REVIEW

(Kably, 2017) The research paper focuses on the discussions for the anti-profiteering wing and explains the section 171(1) of CGST Act 2017 in detail. The most of businesses are concerned with the anti-profiteering as it will conduct the pre and post GST calculations and profit and other things will be carefully analysed so there is insecurity of the businesses about it but ultimately it is boon for the customers and will protect the interest of the customers.

(Sapna Agarwal, 2018)In the research paper HUL company says that Anti-Profiteering clause has put the FMCG Sector in trouble as cost of inputs is increasing day by day but there is restriction on increasing the base prices of the products so not only increasing the base price is difficult but also reducing the MRP of the products is almost impossible so in both the situations companies have to face the GST Anti-Profiteering as no company can loss the profit of its own and reduce the prices and with anti-profiteering GST clause kind of fear and insecurity is seen in the FMCG sector because the things after the anti-profiteering are now transparent and companies are not able to gain the extra profits.

(Seth, 2019) The article focuses on the profiteering amount Rs. 90 crore is charged on the Nestle company for not passing the benefit of GST in form of reduced price to the customers and Nestle has already deposited Rs. 16 crores out of 90 crores and remaining 73 crores the company has to deposit within the next three months.

(PTI, 2019) The Article claims that FMCG firms are on the top in the number of complaints related with GST Anti-Profiteering according to the data 42 consumers have filled the complaint for this and of them various companies are not passing the benefit of GST to the consumers. This list includes the major giants like HUL (Hindustan Unilever Limited), P\&G-Procter and Gamble, Nestle etc.

(PTI, HUL Nestle Voluntarily give Rs. 175 crores , 2018) HUL and Nestle together voluntarily deposits Rs. 175 crores to the Consumer Welfare Funds accepting that company has failed to meet the GST Anti-Profiteering law. From Rs. 175 crores HUL deposits Rs. 160 crores and Nestle deposits 15 crores but NAA doesn't spare the company and tells that after examining the case in detail it will tell the final amount of profiteering and these advances paid amount will be deducted from the total anti-profiteering amount.

(Taxmann's Corporate Professionals Today, 2020) The article throws light on the wrong methodology adopted by the Nestle Company for passing the benefit of GST to the consumers. As per the article company has increased the base prices of the products of 300 SKUs- Stock Keeping Units and actual benefit was not passed to the consumers.

(CP, 2018) The article focuses on the calculations done in case of Nestle Maggi Anti-Profiteering when in GST system there was rate change from $18 \%$ to $12 \%$ on the Maggi product of Nestle and Company has increased the base price from $3.96 \mathrm{Rs}$ to $4.17 \mathrm{Rs}$ and charged the same price of 5 Rs before and after the GST rate amendment.

(Agarwal, 2019) The article throws light on the calculations done in case of Nestle chocolates when there was rate change from $28 \%$ to $18 \%$ but still the price was not reduced for the customers and anti-profiteering was done. The author highlights that chocolates will bitter for the company as high profiteering is done and penalty of 90 crores is imposed on the company.

(Lavi, 2019) The author has highlighted the success of anti-profiteering under GST system and explains the benefits of it as most of businesses are now under the scanner of anti-profiteering. There are almost more than 100 cases which have come under the scanner of Anti-Profiteering and many high profile companies are included in the list. The another aspect of it is explained that the section 171 of CGST is among the simplest and shortest section of the GST Act yet very tricky for the business who adopt unfair profiteering activities.

\section{OBJECTIVES OF THE STUDY}

To analyse the court case in detail.

Evaluate the findings and decision delivered by the NAA.

\section{RESEARCH METHODOLOGY}

The study has been done with the help of secondary data sources. The particular case file number 70/2019 DGAP v/s Nestle India Limited has been taken as the core of the study and other supporting data from the government sites of GST has taken as reference. The whole case file has been analysed in detail with calculations.

\section{DATA DISCUSSION AND ANALYSIS}

Case no. : 70/2019

Case: DGAP v/s M/s Nestle India Limited

Date of Institution: 12.06.2018

Investigation Reports dated: 8.10.2018, 16.01.2019, to 01.06.2019. 


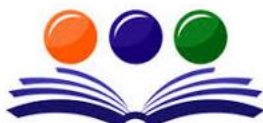

GRAND ACADEMIC PORTAL RESEARCH JOURNALS

Period of Investigation: 15.11.2017 to 30.06.2018

Documents submitted by the Nestle Company of November 2017 to March 2018:

1. GSTR-1 Returns(which shows sales per month)

2. Outward supplies invoices from GSTN- Goods and Services Tax Network

3. 5 random invoices of each month of the mentioned period

4. Total SKUs which are involved in manufacturing.

Nestle company is FMCG company which manufactures and sells food processing products such as coffee, chocolates, noodles, pasta and other food items under different brand names like Maggi, Nescafe etc. On 15.11.2017 there was a major change in the GST rate structure and rates of GST were reduced in two major categories from $28 \%$ to $18 \%$ and from $18 \%$ to $12 \%$ these rates were reduced so that customers get the products at a cheaper rates. One complaint was received against Nestle India that before 15.11.2017 amendment the packet of Maggi of 35 grams at 18\% GST was Rs. 5 and after 15.11 .2017 when rates were reduced on Maggi from 18\% to 12\% then also a packet of Maggi of 35 grams costs same Rs. 5

Maggi Product

\begin{tabular}{|l|l|l|}
\hline Particulars & Before 15.11 .2017 & After 15.11 .2017 \\
\hline Weight of product & 35 grams & 35 grams \\
\hline GST Rate & $18 \%$ & $12 \%$ \\
\hline Price of the product & Rs. 5 & Rs.5 \\
\hline
\end{tabular}

So the customer complained that with GST customer has no benefit and there is no price reduction after the 15.11.2017 as rate is reducing but price is same. In the investigation and calculations it was found that Nestle has increased the base price of the product Maggi, the calculation is as under,

\begin{tabular}{|l|l|l|l|}
\hline Before 15.11 .2017 & & After 15.11 .2017 to & 28.02 .2018 \\
\hline Base Price & 3.96 Rs. & Base Price & 4.17 Rs. \\
\hline$+18 \%$ GST & 0.71 Rs. & $+12 \%$ GST & 0.50 Rs. \\
\hline Total & 4.67 Rs. & Total & 4.67 Rs. \\
\hline
\end{tabular}

Quantity was same for both periods 35 grams

It is clear from the above calculations that base price was increased by company when there was rate reduction in GST. From 3.96 Rs. To 4.17 Rs.

Rs. 0.21 was increased on per packet of Rs.5 Maggi so this turns the case as anti-profiteering under GST as per the section 171 of CGST Act. Any benefit due to GST must be passed to the customers but nestle had increased the profit of the company on the name of GST and benefit which should be passed to the consumers was pocketed by the company. The actual price for the per packet of Maggi must be,

\begin{tabular}{|l|l|}
\hline Base price & 3.96 Rs \\
\hline$+12 \%$ GST & 0.47 Rs. \\
\hline Total & 4.43 Rs. \\
\hline
\end{tabular}

Another products in which profiteering found was Kitkat Chocolate of Rs. 10 and Nescafe Sunrise Coffee of Rs. 2 when the rate of chocolates and rate of instant coffee was reduced on 15.11 .2017 from $28 \%$ to $18 \%$

Calculations in case of Product Nescafe Sunrise (Instant Coffee)

\begin{tabular}{|l|l|l|l|}
\hline Before 15.11 .2017 & & After 15.11 .2017 to & 28.02 .2018 \\
\hline Base Price & 1.57 Rs. & Base Price & 1.70 Rs. \\
\hline$+28 \%$ GST & 0.43 Rs. & $+18 \%$ GST & 0.30 Rs. \\
\hline Total & 2.00 Rs. & Total & 2.00 Rs. \\
\hline
\end{tabular}

Quantity unchanged 2.2 grams in both periods

Base Price Increase 1.70-1.57=0.13 Rs

Actual fair price must be,

\begin{tabular}{|l|l|}
\hline Base price & 1.57 Rs \\
\hline$+18 \%$ GST & 0.27 Rs. \\
\hline Total & 1.84 Rs. \\
\hline
\end{tabular}

Calculations in case of Product Kitkat (Chocolate)

\begin{tabular}{|l|l|l|l|}
\hline Before 15.11 .2017 & & After 15.11 .2017 to & 28.02 .2018 \\
\hline Base Price & 7.80 Rs. & Base Price & 8.50 Rs. \\
\hline$+28 \%$ GST & 2.18 Rs. & $+18 \%$ GST & 1.53 Rs. \\
\hline Total & 10.00 Rs. & Total & 10.00 Rs. \\
\hline Quantity & 12.8 grams & Quantity & 13.2 grams \\
\hline
\end{tabular}

Base Price increase 8.50-7.80=0.70 Rs.

Actual fair price must be, 


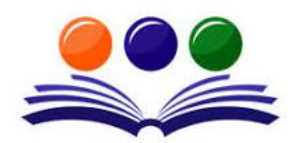

GRAND ACADEMIC PORTAL RESEARCH JOURNALS
A GLOBAL JOURNAL OF SOCIAL SCIENCES

( ISSN - 2581-5830 )

Impact Factor: SJIF - 4.998, IIFS - 4.375

\begin{tabular}{|l|l|}
\hline Base price & $7.80 \mathrm{Rs}$ \\
\hline$+18 \%$ GST & $1.40 \mathrm{Rs}$. \\
\hline Total & $9.20 \mathrm{Rs}$. \\
\hline
\end{tabular}

When the reasons and clarifications were asked from the Nestle company for such increase in the base prices of the product, in defence it gave the following reasons and clarifications:

- Coins below 25 Paisa is not available and practically in the cash transactions it is not possible and MRPMaximum Retail Price in fractions paisa is not permitted under legal metrology rules.

- It takes 6 to 9 months' time to incorporate and implement changes.

- Other discounts were given to the customers due to GST rate reduction and proving this point invoices were submitted.

- In the clarifications company said that whenever it was practical company had passed the benefit to the customers and it has also reminded each distributor about the price obligations and GST benefit of price reduction must be passed to the customers.

- In defence company said it has separated and kept aside the extra amount earned as a current liability to pass the benefit to the customers and this extra and separated amount company has not counted as profit or sales and this amount will be utilized by company in future discounts and offers for the customers only. (This amount kept aside is the amount company has charged by increasing the base prices)

- In case of Kitkat chocolate company had kept the same price but increased the Quantity from 12.8 grams to 13.2 grams.

- In case of coffee Nescafe Sunrise Company can't increase the quantity of Rs. 2 packet as it would change the taste of coffee and it will taste bitter in one cup.

- The company has passed the benefit of rates reduction on the other packets like Maggi of Rs. 12 was reduced to Rs. 11 and Kitkat of Rs 5.7 grams quantity was increased to 8.6 grams.

- For Nescafe classic of 25 grams of Rs. 80 was reduced to Rs.70 and in case of Munch chocolate of Rs. 5 of 10.1 grams quantity was increased 11.1 .

In this way Nestle company defended and explained that Rs. 2, 5,10 packets because of paisa difference in amounts it was not practical and possible to pass the benefit of reduced price but on the larger packets it has passed the benefit of reduced price and in some products the quantity was increased.

Investigation and Facts by DGAP

- In the detail investigation it was found that there were no discounts which were provided by the company for GST but the discounts given were of general and regular furtherance of business which company gives for customer retention and these discounts have nothing to do with GST.

- $\quad$ Base prices of the products were deliberately increased to earn extra profit.

- As per section 171 of CGST Act only benefit by way of reduction in price is allowed other means of benefits to customers as nestle did by increasing quantity of the products is not allowed as all products MRP was not changed but another method of increasing quantity was taken.

- 374 SKUs prices were not reduced instead of reducing the prices base prices were increased and MRPs were kept same.

- In case of 5 Rs Maggi and 2 Rs. Coffee neither quantity was increased nor price was reduced.

- Amount set aside was as follow,

\begin{tabular}{|l|l|}
\hline Particulars & Amount in crores \\
\hline Chocolate products & 0.7 \\
\hline Noodles and Pasta & 3.3 \\
\hline Wafer chocolates & 6.0 \\
\hline Instant coffee & 1.1 \\
\hline Others & 1.5 \\
\hline Total & 12.6 \\
\hline
\end{tabular}

On set aside Amount Company claimed that this amount belongs to the customers who have already purchased the products and this amount is not for future use of the company and ordered the company to deposit this 12.6 crores amount to CWFs.

- It was proved that wrong interpretation of section 171 was done by the company.

- In investigation calculation of profiteering monthly sales data was taken as base which was provided by the company from 15.11.2017 to 30.06.2018. The profiteering amount was found by calculation is Rs. $89,73,16,383$ out of which nestle had already deposited Rs.16,58,32,723 to CWFs so remaining amount of Rs. 73,14,83,660 NAA ordered to deposit this remaining amount to CWFs.

- It is correct that company has to follow legal metrology rules 2011 and can't keep the MRP in 25 or 50 paisa however not a single effort was made by the company to refix the MRP and packaging which was compulsory in GST to change the packaging and reduce MRP. 
